\title{
Monitoria positiva
}

Recebido em 29.04.2015. Aprovado em 05.05. 2015 Avaliado pelo sistema double blind review

\author{
Josiane Knust Sampaio \\ cejoaquimtavora@educacao.rj.gov.br \\ Colégio Estadual Joaquim Távora - Niterói - RJ - Brasil
}

\section{Resumo}

O projeto "Monitoria Positiva" tem por objetivo estabelecer uma equipe de monitoria formada por alunos do Ensino Médio, que trabalhará em parceria com a equipe docente, promovendo encontros para estudo dirigido de matemática. Com este projeto o colégio pretende possibilitar a aprendizagem e utilização de diferentes linguagens matemáticas, aumentar o nível de compreensão dos alunos em conceitos matemáticos e, principalmente, desenvolver o hábito do trabalho coletivo favorecendo a estruturação do pensamento lógico.

Este projeto se justifica pois detectamos uma defasagem no ensino-aprendizagem da matemática que vem prejudicando significativamente o alcance das metas estipuladas pelo colégio. Nesta proposta serão formados grupos de alunos monitores que atuaram em parceria com a equipe docente para dirimir dúvidas e debater assuntos referentes a disciplina em questão, atendendo alunos do $9^{\circ}$ Ano do Ensino Fundamental e alunos do Ensino Médio. Para atingir estes objetivos contaremos com a ajuda de alguns professores da UFF que auxiliarão nossos alunos e professores na conquista de resultados positivos.

Com esta parceria planejamos oportunizar novas experiências aos nossos alunos, tornando-os responsáveis pelo bom rendimento do grupo, além de contribuírem para o aumento da renda familiar. Desta maneira, 0 aluno se mantém vinculado à escola não apenas por sua formação básica, mas atrelando a ela a sua capacitação profissional inicial. Pretendemos conseguir que uns estimulem os outros a participarem de um reforço coletivo, interagindo na construção do conhecimento e reduzindo substancialmente o percentual de reprovações em matemática.

Inicialmente, serão cadastrados 5 monitores, número que poderá ser ampliado nos anos subsequentes, podendo também ser aplicado para outras disciplinas. Para esta proposta necessitamos de um investimento de, aproximadamente, $\mathrm{R} \$ 63.000,00$, divididos em despesa com capital, custeio e pagamento de terceiros. Em contrapartida o colégio disponibilizará cerca de $\mathrm{R} \$ 82.000,00$ em serviços e despesas.

Com este projeto, que atende aos requisitos do edital, o Colégio Estadual Joaquim Távora pretende trazer resultados positivos para esta comunidade escolar, introduzindo o hábito do estudo coletivo, reduzindo as taxas de reprovação e colaborando para o alcance das metas federais e estaduais de desempenho escolar.

Palavras-chaves: Educação. Monitoria. Plano de empreendimento. Ensino de matemática. 


\section{Caracterização da escola}

Nome completo da escola: Colégio Estadual Joaquim Távora

Ano de fundação: 1924

Bairro/Cidade: Icaraí - Niterói

Contato: (21) 3611-2287 / e-mail: cejoaquimtavora@educacao.rj.gov.br

Número de alunos: 1.012

Séries atendidas: $2^{\circ}$ segmento do Ensino Fundamental - $6^{\circ}$ ao $9^{\circ}$ Ano (Regular e Educação de Jovens e Adultos- EJA) e Ensino Médio (Regular e NEJA)

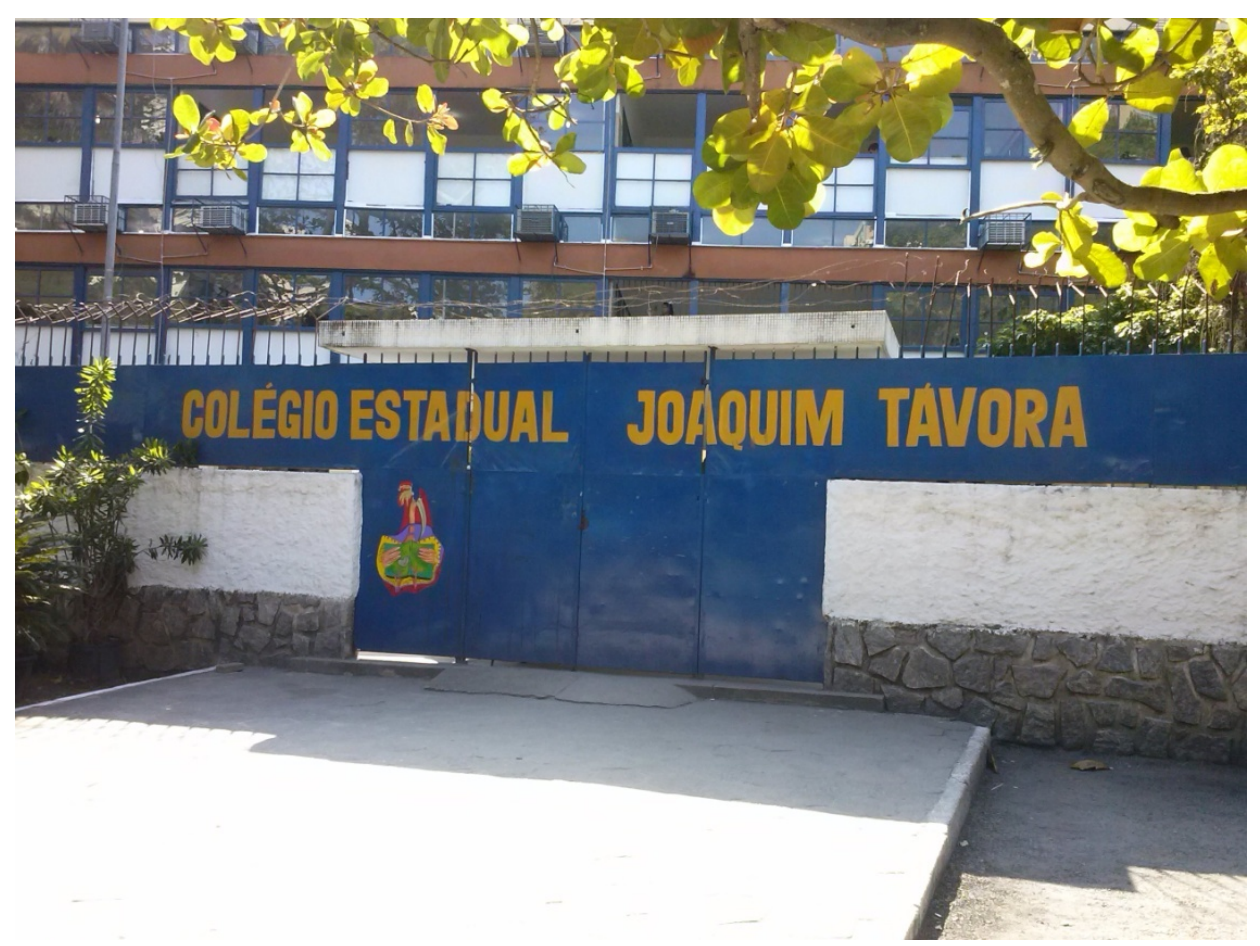

\section{Missão:}

Oportunizar ao educando, aquisição dos conhecimentos necessários ao desenvolvimento da inteligência ética, da habilidade, da iniciativa e da competência na resolução dos problemas, desenvolvendo valores que despertem para uma consciência de cidadão responsável por uma convivência democrática.

\section{Visão:}

Garantir o Ensino Público de qualidade com compromisso e responsabilidade gerando valor e reconhecimento no âmbito da rede educacional do Estado do Rio de Janeiro, estando entre as 10 melhores classificadas do município de Niterói pelo IDEB até 2017.

\section{Instalações}

O prédio principal do Colégio Estadual Joaquim Távora possui três andares. Na parte térrea encontram-se cantina, laboratório de ciências, banheiro dos professores, setor de pessoal, sala da direção, secretaria, mecanografia, setor de pessoal, laboratório de informática, sala de orientação escolar, sala do PROEIS Programa Estadual de Integração na Segurança, pátio coberto, banheiro para cadeirante e uma sala de recursos sendo preparada. No $1^{\circ}$ andar existem 9 salas de aula, 2 banheiros (um masculino e um feminino) e 1 biblioteca escolar. No $2^{\circ}$ andar constam 8 salas de aula, 1 sala de professores, 1 sala da coordenação, 1 banheiro para professores, 1 vestiário de funcionários, 1 sala de artes e 1 auditório. 
Há dois prédios anexos, um onde está localizado o refeitório, a cozinha, a despensa e o banheiro para funcionários. E outro anexo com a quadra coberta, a quadra descoberta, dois vestiários para alunos (um masculino e um feminino), a sala de material de educação física, a sala da banda e a casa do zelador. Além destas edificações, o colégio ainda possui uma extensa área livre bem arborizada de aproximadamente 3000 $\mathrm{m}^{2}$, onde se localiza também um estacionamento para funcionários. As áreas internas do colégio foram pintadas recentemente, mas ainda aguardamos uma obra nos banheiros e nas partes externas do prédio.

\section{Breve histórico}

O quadro a seguir apresenta a relação dos acontecimentos mais relevantes para a evolução da escola, desde a fundação até hoje.

\begin{tabular}{|c|c|}
\hline Ano & Acontecimentos relevantes \\
\hline 1924 & Fundação da escola com o nome de Escola Arthur Bernardes. \\
\hline 1930 & Mudança do nome para Grupo Escolar Joaquim Távora, funcionando com $1^{\mathrm{a}}$ a $4^{\mathrm{a}}$ série primária. \\
\hline 1934 & Construção do anexo Jardim de Infância Júlia Cortines \\
\hline 1954 & Início da construção do atual prédio. \\
\hline 1978 & $\begin{array}{l}\text { O Colégio Alcebíades Peçanha é anexado ao Joaquim Távora, passando a se chamar Colégio Estadual } \\
\text { Joaquim Távora. }\end{array}$ \\
\hline 1979 & Criação do logotipo da escola e da sigla CEJOTA. \\
\hline 1982 & Inauguração da quadra coberta da escola. \\
\hline 1982 & $\begin{array}{l}\text { O colégio passou a oferecer curso técnico profissionalizante em contabilidade e assistente de } \\
\text { administração. }\end{array}$ \\
\hline 1983 & Inauguração do refeitório da escola. \\
\hline 1994 & O Jardim de Infância Júlia Cortines foi desassociado do Joaquim Távora. \\
\hline 1998 & Início da terminalidade do $1^{\circ}$ segmento do Ensino Fundamental. \\
\hline 1999 & O colégio deixou de oferecer os cursos técnicos \\
\hline 2003 & Início da oferta da EJA no noturno. \\
\hline 2005 & $1^{\text {a }}$ turma de EJA formada pela escola. \\
\hline 2007 & O colégio atinge a meta do IDEB 2007 \\
\hline 2013 & Oferta do Nova EJA com o Módulo I,inicialmente. \\
\hline 2013 & O colégio volta a atingir a meta do IDEB depois de algumas crises internas \\
\hline
\end{tabular}

\section{Professores e funcionários}

A equipe é formada por 128 professores, distribuídos da seguinte forma:

\begin{tabular}{|l|l|}
\hline Disciplina / Área & Quant. de professores \\
\hline Matemática / Resolução de Problemas Matemáticos & 17 \\
\hline Língua Portuguesa / Produção Textual & 18 \\
\hline Língua Estrangeira - Inglês & 7 \\
\hline Língua Estrangeira - Espanhol & 2 \\
\hline História & 7 \\
\hline Geografia & 11 \\
\hline Biologia / Ciências Físicas e Biológicas & 11 \\
\hline
\end{tabular}




\section{Josiane Knust Sampaio}

\begin{tabular}{|l|l|}
\hline Química & 5 \\
\hline Física & 4 \\
\hline Arte & 4 \\
\hline Educação Física & 9 \\
\hline Sociologia & 2 \\
\hline Filosofia & 2 \\
\hline Ensino Religioso & 2 \\
\hline
\end{tabular}

Do total de professores,118 são efetivos, 5 GLP - Gratificação por Lotação Prioritária (Professores de nossa escola e de outras unidades) e ainda 5 contratados, uma vez que 16 efetivos estão licenciados ou foram readaptados e atuam como agentes de leitura ou professores articuladores. Temos 17 docentes (DOC II) atuando em função extraclasse (direção, secretaria, coordenação, etc). A grande maioria dos docentes está na escola há mais de 10 anos e possuem experiência também nas redes particular e municipal de ensino, além de muitos já possuírem especialização, mestrado e alguns, doutorado.

A escola conta também com 1 Bibliotecária, 19 funcionários de apoio, sendo que destes 9 são efetivos e 10 terceirizados, distribuídos assim: 5 merendeiras, 3 serventes, 5 auxiliares de serviços gerais, 3 porteiros, além de 3 que se encontram licenciados.

Perfil dos alunos

Os alunos estão distribuídos por séries e turnos da seguinte maneira:

\begin{tabular}{|c|c|c|c|c|c|c|c|c|}
\hline \multirow[b]{2}{*}{ Série/Ano } & \multirow{2}{*}{$\begin{array}{l}\text { Média } \\
\text { de } \\
\text { idade }\end{array}$} & \multirow{2}{*}{$\begin{array}{l}\text { Total de } \\
\text { alunos }\end{array}$} & \multicolumn{2}{|l|}{ Manhã } & \multicolumn{2}{|l|}{ Tarde } & \multicolumn{2}{|l|}{ Noite } \\
\hline & & & $\mathrm{N}^{0}$ alunos & $\begin{array}{l}N^{0} \\
\text { turmas }\end{array}$ & $\mathrm{N}^{0}$ alunos & $\begin{array}{l}\mathrm{N}^{0} \\
\text { turmas }\end{array}$ & $\mathrm{N}^{0}$ alunos & $\begin{array}{l}N^{0} \\
\text { turmas }\end{array}$ \\
\hline $6^{\circ}$ ano & 11,5 & 123 & - & - & 123 & 4 & - & - \\
\hline $7^{\circ}$ ano & 12,5 & 141 & - & - & 141 & 5 & - & - \\
\hline $8^{\circ}$ ano & 13,5 & 88 & - & - & 88 & 3 & - & - \\
\hline $9^{\circ}$ ano & 14,7 & 78 & - & - & 78 & 3 & - & - \\
\hline $1^{\circ}$ E.M. & 15,9 & 199 & 199 & 6 & - & - & - & - \\
\hline $2^{\circ}$ E.M. & 16,8 & 93 & 93 & 3 & - & - & - & - \\
\hline $3^{\circ}$ E.M. & 18 & 80 & 80 & 3 & - & - & - & - \\
\hline $6^{\circ}$ ano (EJA) & N/A & 11 & - & - & - & - & 11 & 1 \\
\hline $7^{\circ}$ ano (EJA) & N/A & 18 & - & - & - & - & 18 & 1 \\
\hline $8^{\circ}$ ano (EJA) & $\mathrm{N} / \mathrm{A}$ & 18 & - & - & - & - & 18 & 1 \\
\hline $9^{\circ}$ ano (EJA) & $\mathrm{N} / \mathrm{A}$ & 23 & - & - & - & - & 23 & 1 \\
\hline $1^{0}$ Mód.(NEJA) & $\mathrm{N} / \mathrm{A}$ & 30 & - & - & - & - & 30 & 1 \\
\hline $2^{\circ}$ Mód.(NEJA) & $\mathrm{N} / \mathrm{A}$ & 34 & - & - & - & - & 34 & 1 \\
\hline $3^{\circ}$ Mód.(NEJA) & $\mathrm{N} / \mathrm{A}$ & 44 & - & - & - & - & 44 & 1 \\
\hline $4^{\circ}$ Mód.(NEJA) & $\mathrm{N} / \mathrm{A}$ & 32 & - & - & - & - & 32 & 1 \\
\hline TOTAL & - & 1.012 & 372 & 12 & 430 & 15 & 210 & 8 \\
\hline
\end{tabular}

O CEJOTA vem atraindo jovens dos bairros e cidades vizinhas, atendendo, assim, estudantes de diversas comunidades e cidades circunvizinhas, como Maricá e São Gonçalo. Por esta característica, possui um corpo 
discente bem heterogêneo.

Os alunos, de modo geral, participam bem das atividades propostas e se envolvem ainda em cursos e atividades esportivas oferecidas pela escola no contraturno. Cerca de $25 \%$ dos alunos do ensino médio diurno já trabalham, a maioria em parceria com o CIEE (Centro de Integração Empresa- Escola). Os pais são sempre convidados a participar ativamente das atividades da escola e da vida escolar de seus filhos, não havendo ainda uma participação significativa. Através de projetos, temos conseguido aumentar esta participação. Este ano criamos um Guia do Estudante que contém os horários, o calendário e as principais regras da escola, facilitando o acompanhamento dos responsáveis.

Características do entorno

O Colégio Estadual Joaquim Távora está localizado em Niterói, município do estado do Rio de Janeiro que conta com uma população estimada em 487.327 habitantes (Censo 2010) e uma área de 129,3 km², sendo a quinta cidade mais populosa do estado e a de maior Índice de Desenvolvimento Humano. A cidade de Niterói é um dos principais centros financeiros, comerciais e industriais do Rio de Janeiro, sendo a $12^{\mathrm{a}}$ entre as 100 melhores cidades brasileiras para negócios. Segundo dados do IBGE/2010, o Produto Interno Bruto (PIB) nominal de Niterói foi de $\mathrm{R} \$ 11,2$ bilhões, figurando como o quinto município com maior PIB do Rio de Janeiro.

O Colégio Estadual Joaquim Távora está localizado em um espaço privilegiado desta cidade, já que se situa dentro do Parque Prefeito Ferraz, um grande parque municipal mais conhecido como Campo de São Bento, a área verde mais popular da cidade, no bairro de Icaraí. Em recente pesquisa, diagnosticou-se que a população do bairro é prioritariamente de classe média à classe média alta, com renda per capita em torno de 6.000 reais, dezenove vezes mais alta que a média nacional. É um bairro de características residenciais e, segundo dados de 2010, sua população é de 67.004 habitantes.

O serviço de ônibus urbanos consiste no único meio de transporte público intramunicipal da cidade de Niterói. Há pouco menos de cinquenta linhas de ônibus em atividade, todas operadas por empresas particulares. A maior parte das linhas de ônibus municipais passa pelo bairro de Icaraí. Existem também algumas linhas intermunicipais que cruzam o bairro. 


\section{Identificação do problema e da oportunidade}

A identificação do problema partirá de um diagnóstico da Unidade Escolar. Para isso, foram observadas as principais avaliações externas, avaliações da equipe pedagógica, bem como relatórios internos de desempenho.

\section{Avaliação Federal: \\ IDEB \\ Resultado IDEB para $8^{\mathrm{a}}$ série $/ 9^{\circ}$ ano}

IDEB - Resultados e Metas

\begin{tabular}{|c|c|c|c|}
\hline Resultado: & Escola & UF: & RJ \\
\hline Município: & NITERÓl & Nome da Escola: & CE JOAQUIM TAVORA \\
\hline Rede de ensino: & Estadual & Série / Ano: & $8^{3}$ série $/ 9^{\circ}$ ano \\
\hline
\end{tabular}

\begin{tabular}{|c|c|c|c|c|c|c|c|c|c|c|c|c|c|}
\hline \multirow[b]{2}{*}{ Escola $*$} & \multicolumn{5}{|c|}{ Ideb Observado } & \multicolumn{8}{|c|}{ Metas Projetadas } \\
\hline & $2005 \approx$ & $2007 \approx$ & $2009 \div$ & $2011 \nRightarrow$ & $2013 \approx$ & $2007 \approx$ & $2009 \approx$ & $2011=$ & $2013=$ & $2015 \div$ & $2017 \approx$ & $2019 \approx$ & $2021 *$ \\
\hline CE JOAQUIM TAVORA & 3.0 & 3.3 & 2.3 & 2.7 & 4.0 & 3.1 & 3.3 & 3.6 & 4.0 & 4.5 & 4.7 & 5.0 & 5.2 \\
\hline
\end{tabular}

Obs:

* Número de participantes na Prova Brasil insuficiente para que os resultados sejam divulgados.

** Solicitação de não divulgação conforme Portaria Inep n 304 de 24 de junho de 2013.

*** Sem média na Prova Brasil 2013.

***** Não divulgado por solicitação da Secretaria/Escola devido a situações adversas no momento da aplicação.

Fonte: INEP

Os resultados marcados em verde referem-se ao Ideb que atingiu a meta.

O Colégio Estadual Joaquim Távora obteve um excelente resultado na última avaliação, uma vez que obteve uma melhora de 1.3 pontos no IDEB observado nas turmas de $9^{\circ}$ ano. Com esta pontuação conseguimos atingir a meta projetada.

O colégio, entre 2007 e 2012, passou por um período de instabilidades internas, que refletiram negativamente no processo ensino-aprendizagem e na motivação de todos os profissionais envolvidos. Ultimamente, conseguimos resgatar o nosso plano de metas e visamos reestabelecer a credibilidade que a comunidade sempre teve no trabalho desenvolvido por esta unidade escolar. 


\section{Avaliação estadual}

\section{SAERJ}

Resultados do SAERJ 2013:

$3^{\circ}$ ano: Língua Portuguesa

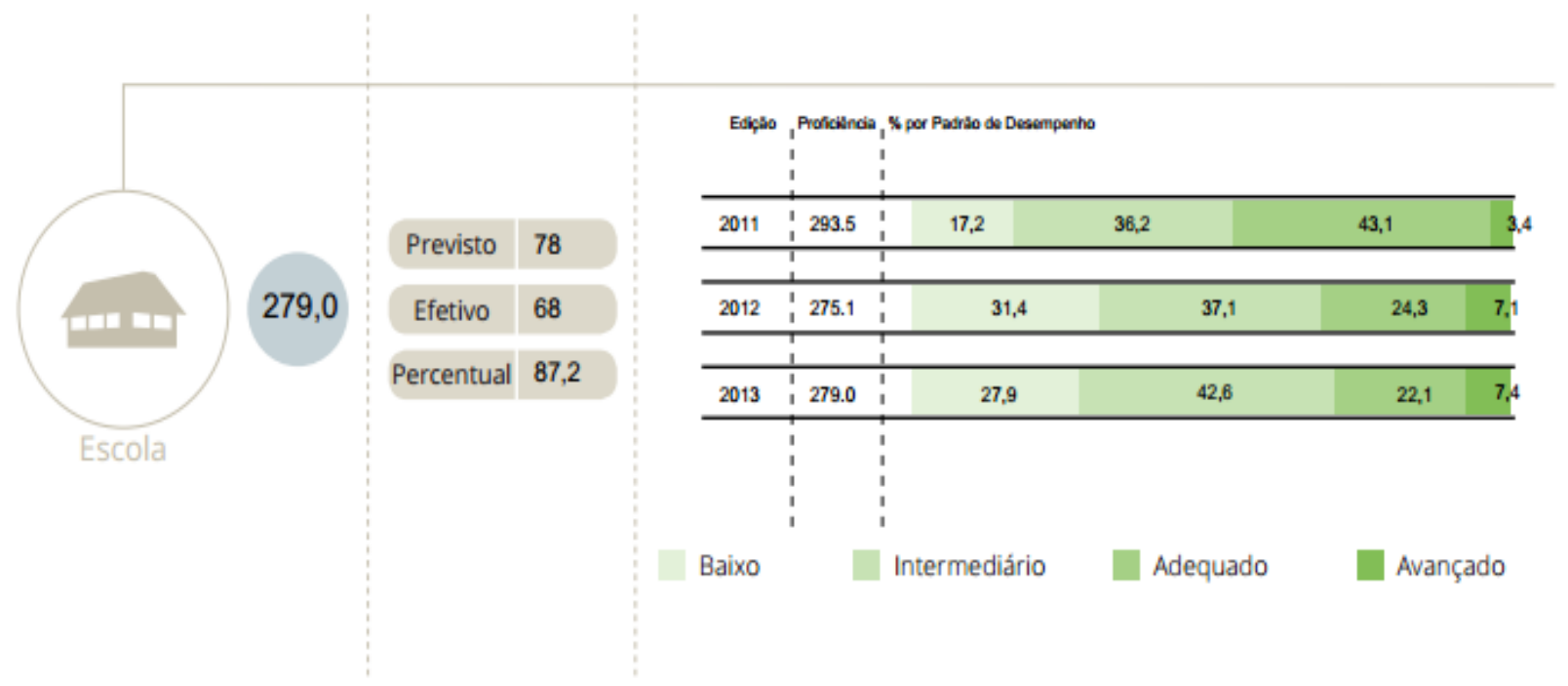

$3^{\circ}$ ANO - Matemática

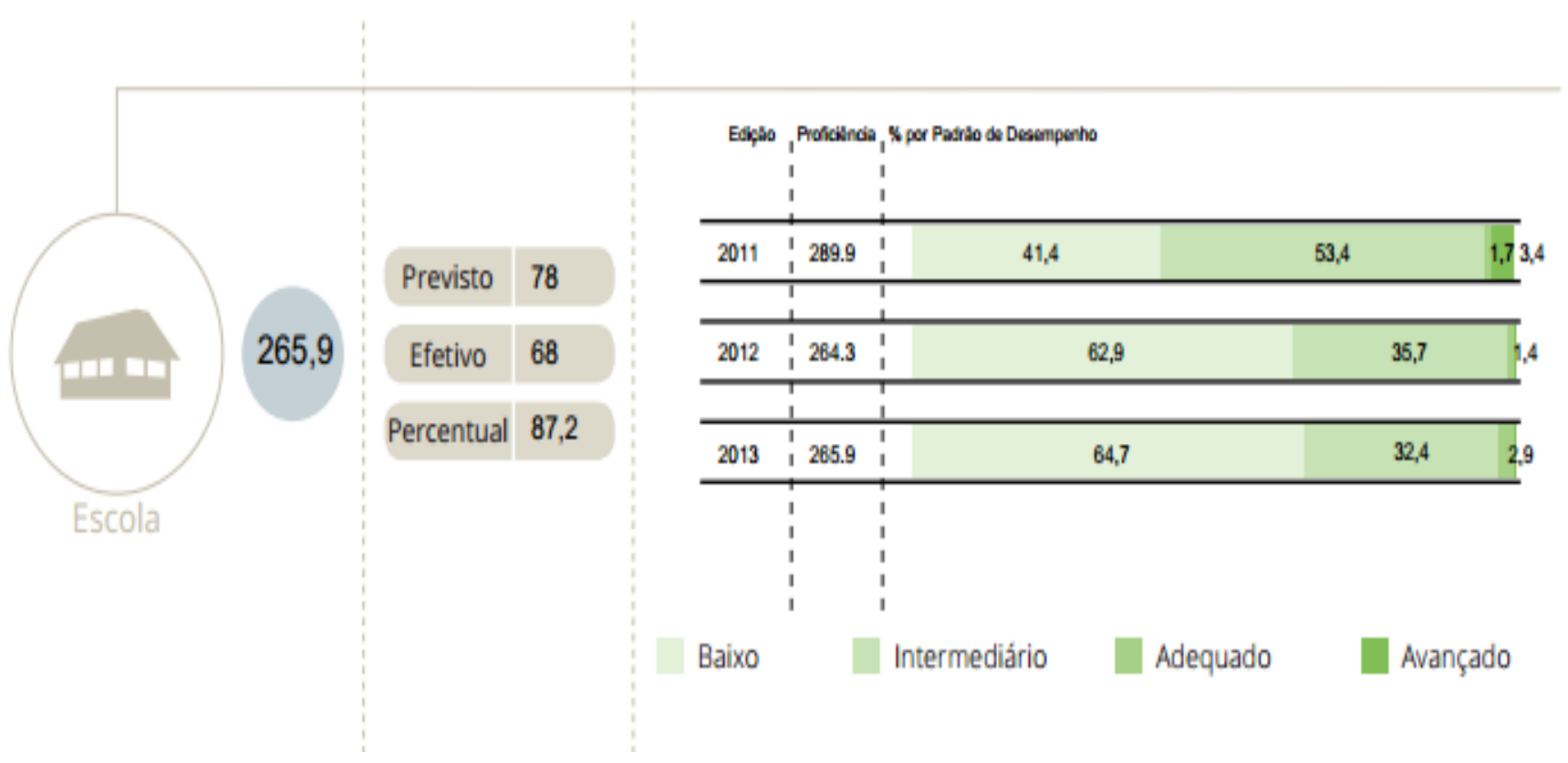


$9^{\circ}$ ANO - Língua Portuguesa

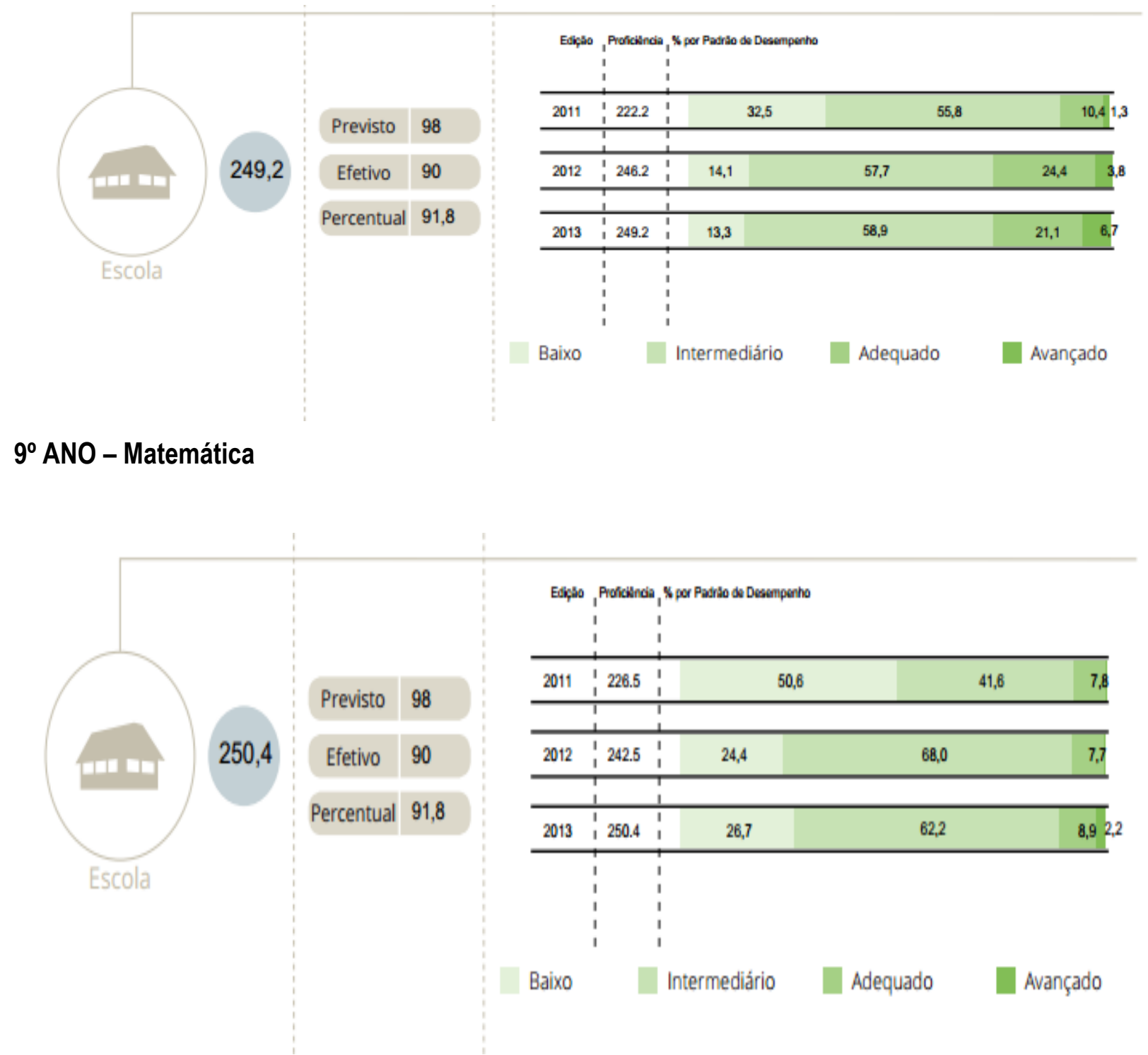

\section{Avaliações e relatórios internos}

\section{Ensino Fundamental}

\begin{tabular}{|c|c|c|c|c|c|c|c|}
\hline Série/Ano & $\begin{array}{l}\text { Matrículas } \\
\text { iniciais }\end{array}$ & Evasão & Transf. & $\begin{array}{l}\text { Matrículas } \\
\text { finais }\end{array}$ & Disciplinas & Aprov. & Reprov. \\
\hline \multirow{6}{*}{$6^{\circ}$ ano } & \multirow{6}{*}{140} & \multirow{6}{*}{07} & \multirow{6}{*}{13} & \multirow{6}{*}{120} & Português & 85 & 35 \\
\hline & & & & & Matemática & 108 & 12 \\
\hline & & & & & História & 113 & 07 \\
\hline & & & & & Geografia & 111 & 09 \\
\hline & & & & & Ciências & 114 & 06 \\
\hline & & & & & Res. de Prob. & * & * \\
\hline
\end{tabular}




\begin{tabular}{|c|c|c|c|c|c|c|c|}
\hline & & & & & Mat. & & \\
\hline & & & & & $\begin{array}{lll}\text { Leitura } & \text { e } & P . \\
\text { Textual } & & \end{array}$ & * & * \\
\hline & & & & & L. Estrangeira & 95 & 25 \\
\hline & & & & & Ed. Física & 114 & 06 \\
\hline & & & & & Artes & 105 & 15 \\
\hline & & & & & Português & 58 & 12 \\
\hline & & & & & Matemática & 61 & 09 \\
\hline & & & & & História & 46 & 24 \\
\hline & & & & & Geografia & 51 & 19 \\
\hline & & & & & Ciências & 66 & 04 \\
\hline $7^{\circ}$ ano & 68 & 00 & 18 & 70 & $\begin{array}{l}\text { Res. de Prob. } \\
\text { Mat. }\end{array}$ & * & * \\
\hline & & & & & $\begin{array}{lll}\text { Leitura } & \text { e } & P . \\
\text { Textual } & & \end{array}$ & * & * \\
\hline & & & & & L. Estrangeira & 61 & 09 \\
\hline & & & & & Ed. Física & 65 & 05 \\
\hline & & & & & Artes & 66 & 04 \\
\hline & & & & & Português & 61 & 09 \\
\hline & & & & & Matemática & 47 & 24 \\
\hline & & & & & História & 60 & 11 \\
\hline & & & & & Geografia & 67 & 04 \\
\hline & & & & & Ciências & 68 & 03 \\
\hline $8^{\circ}$ ano & 80 & 00 & 09 & 71 & $\begin{array}{l}\text { Res. de Prob. } \\
\text { Mat. }\end{array}$ & * & * \\
\hline & & & & & $\begin{array}{lll}\text { Leitura } & \text { e } & P . \\
\text { Textual } & & \end{array}$ & * & * \\
\hline & & & & & L. Estrangeira & 59 & 12 \\
\hline & & & & & Ed. Física & 68 & 03 \\
\hline & & & & & Artes & 66 & 04 \\
\hline & & & & & Português & 85 & 12 \\
\hline & & & & & Matemática & 65 & 32 \\
\hline 00 & 110 & 00 & 17 & 07 & História & 85 & 12 \\
\hline sallo & 110 & 00 & 11 & (51 & Geografia & 62 & 35 \\
\hline & & & & & Ciências & 93 & 04 \\
\hline & & & & & Res. de Prob. & * & * \\
\hline
\end{tabular}




\begin{tabular}{|l|l|l|l|l|l|}
\hline & \multirow{5}{*}{} & & $\begin{array}{l}\text { Mat. } \\
\text { Leitura e P. }\end{array}$ & $*$ & $*$ \\
Textual & & & \\
\hline & L. Estrangeira & 89 & 08 \\
\hline & Ed. Física & 94 & 03 \\
\hline & Artes & 90 & 07 \\
\hline
\end{tabular}


Ensino Médio

\begin{tabular}{|c|c|c|c|c|c|c|c|}
\hline Série/Ano & $\begin{array}{l}\text { Matrículas } \\
\text { iniciais }\end{array}$ & Evasão & Transf. & $\begin{array}{l}\text { Matrículas } \\
\text { finais }\end{array}$ & Disciplinas & Aprov. & Reprov. \\
\hline \multirow{11}{*}{$1^{\circ}$ ano E.M. } & \multirow{11}{*}{182} & \multirow{11}{*}{11} & \multirow{11}{*}{28} & \multirow{11}{*}{143} & Português & 121 & 22 \\
\hline & & & & & Matemática & 103 & 40 \\
\hline & & & & & História & 126 & 17 \\
\hline & & & & & Geografia & 116 & 27 \\
\hline & & & & & Biologia & 121 & 22 \\
\hline & & & & & L. Estrangeira & 129 & 14 \\
\hline & & & & & Ed. Física & 143 & 0 \\
\hline & & & & & Química & 105 & 38 \\
\hline & & & & & Física & 105 & 38 \\
\hline & & & & & Filosofia & 127 & 16 \\
\hline & & & & & Sociologia & 135 & 8 \\
\hline \multirow{13}{*}{$2^{\circ}$ ano E.M. } & \multirow{13}{*}{104} & \multirow{13}{*}{04} & \multirow{13}{*}{10} & \multirow{13}{*}{91} & Português & 85 & 06 \\
\hline & & & & & Matemática & 83 & 08 \\
\hline & & & & & História & 78 & 13 \\
\hline & & & & & Geografia & 81 & 10 \\
\hline & & & & & Biologia & 91 & 0 \\
\hline & & & & & L. Estrangeira & 79 & 12 \\
\hline & & & & & Ed. Física & 88 & 03 \\
\hline & & & & & Artes & 89 & 02 \\
\hline & & & & & Química & 61 & 30 \\
\hline & & & & & Física & 73 & 18 \\
\hline & & & & & Filosofia & 78 & 13 \\
\hline & & & & & $\begin{array}{l}\text { Res. de Prob. } \\
\text { Mat. }\end{array}$ & & \\
\hline & & & & & Sociologia & 88 & 03 \\
\hline \multirow{12}{*}{$3^{\circ}$ ano E.M. } & \multirow{12}{*}{90} & \multirow{12}{*}{01} & \multirow{12}{*}{14} & \multirow{12}{*}{75} & Português & 69 & 06 \\
\hline & & & & & Matemática & 67 & 08 \\
\hline & & & & & História & 70 & 05 \\
\hline & & & & & Geografia & 72 & 03 \\
\hline & & & & & Biologia & 72 & 03 \\
\hline & & & & & L. Estrangeira & 73 & 02 \\
\hline & & & & & Ed. Física & 75 & 0 \\
\hline & & & & & $\begin{array}{l}\text { Leitura e P. } \\
\text { Textual }\end{array}$ & & \\
\hline & & & & & Química & 62 & 13 \\
\hline & & & & & Física & 71 & 04 \\
\hline & & & & & Filosofia & 75 & 0 \\
\hline & & & & & Sociologia & 73 & 02 \\
\hline
\end{tabular}




\section{Ensino fundamental}

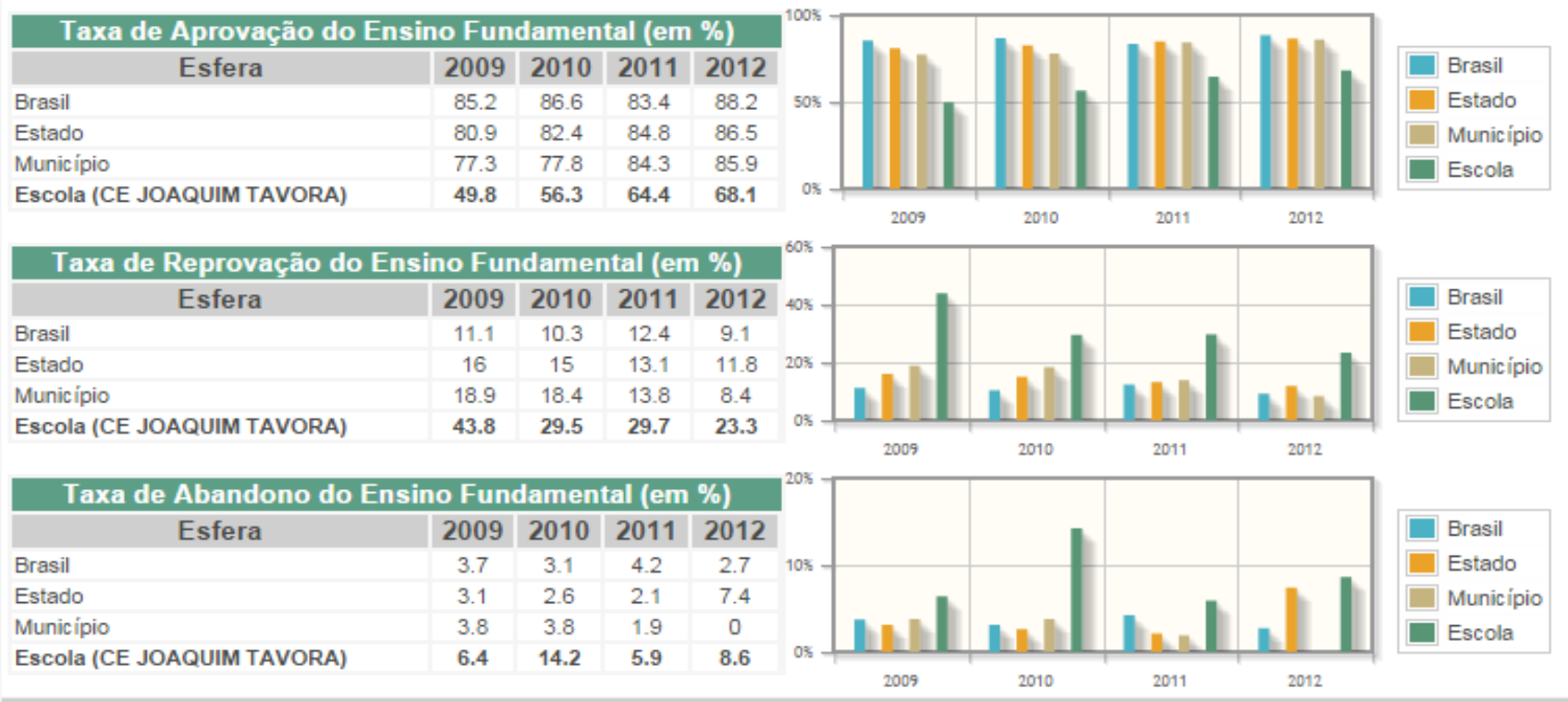

ENSINO MÉDIO

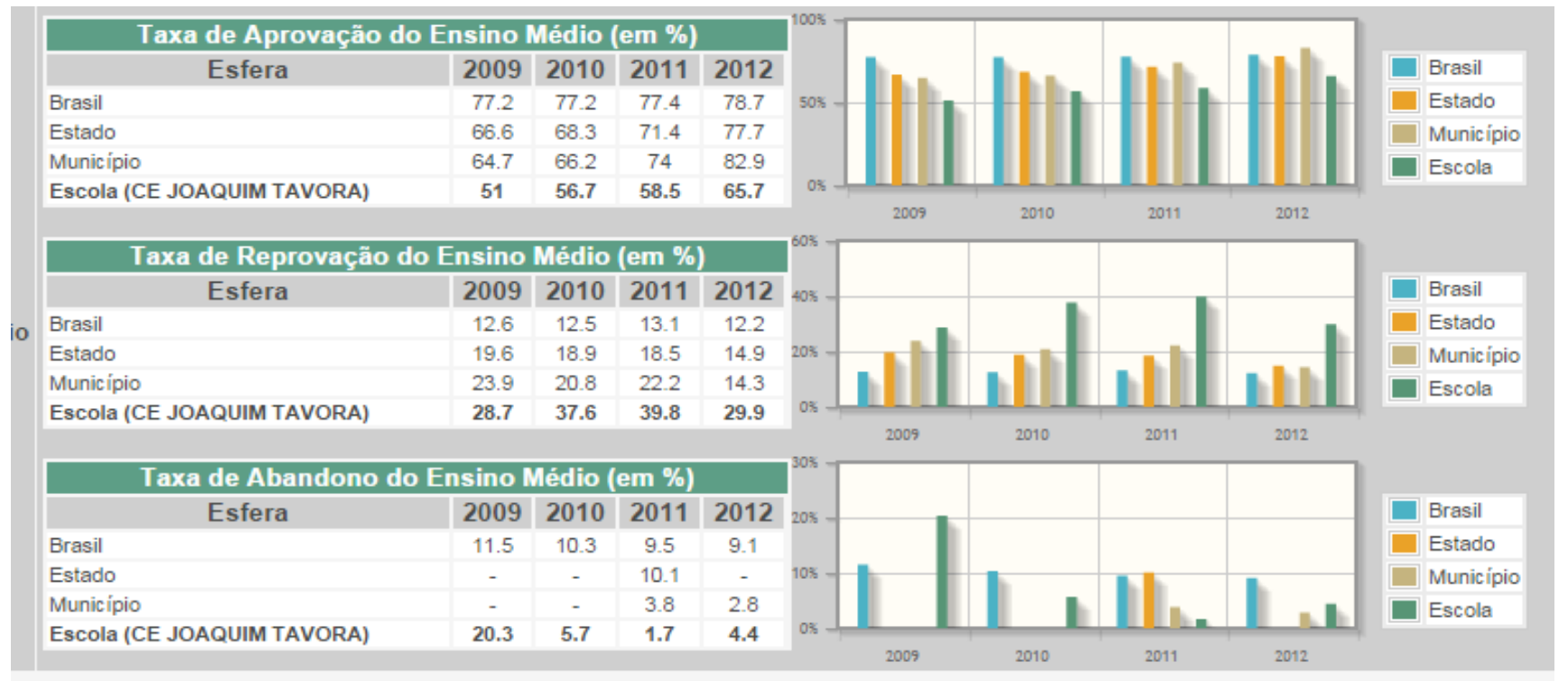

(Fonte: PDE INTERATIVO - MEC)

\section{Principais problemas identificados:}

Analisando os dados coletados, observamos que o colégio vem conseguindo recuperar suas taxas e alcançar suas metas, mas alguns pontos ainda nos causam preocupação e devem receber especial atenção:

O colégio conseguiu elevar consideravelmente o percentual de alunos aprovados nos últimos anos, tanto no Ensino Fundamental quanto no Ensino Médio, mas ainda mantém porcentagem significativa de alunos reprovados e/ou com dependência;

O comprometimento da equipe docente com as avaliações externas ainda não é expressivo, mas com 0 trabalho que vem sendo desenvolvido em nossa unidade, conseguimos alguns avanços;

Os professores têm destacado à falta de interesse e de participação mais ativa de nossos alunos. Tanto que nossas taxas de abandono oscilam anualmente e as turmas de reforço do ensino médio não impulsionam as médias como esperado. Um trabalho que a equipe vem realizando insistentemente junto aos pais e alunos 
para diminuir esta defasagem nas disciplinas

Apesar de haver melhora nos índices de reprovações no Ensino Fundamental, o Ensino Médio ainda apresenta um quadro crítico.

Os resultados em Matemática são os mais preocupantes. As turmas do $2^{\circ}$ e $3^{\circ}$ anos do Ensino Médio já conseguem mostrar um rendimento melhor, mas a participação nas avaliações externas se manteve abaixo do esperado, devido à carência de professor da disciplina em algumas turmas em anos anteriores. Atualmente, contamos com o apoio de professores contratados para suprir esta carência.

\section{Matriz GUT:}

\begin{tabular}{|l|l|l|l|l|l|}
\hline Problemas & G & U & T & GxUxT & Prioridade \\
\hline $\begin{array}{l}\text { Os resultados de Matemática não demonstraram boa } \\
\text { evolução nas últimas medições. }\end{array}$ & 5 & 5 & 4 & 100 & $1^{0}$ \\
\hline $\begin{array}{l}\text { O comprometimento da equipe docente com as } \\
\text { avaliações estaduais não é significativo ainda. }\end{array}$ & 5 & 4 & 4 & 80 & $2^{\circ}$ \\
\hline $\begin{array}{l}\text { As taxas de abandono da escola, no ensino } \\
\text { fundamental e ensino médio, não melhoraram nos } \\
\text { últimos dois anos. }\end{array}$ & 5 & 5 & 3 & 75 & $3^{0}$ \\
\hline $\begin{array}{l}\text { As taxas de reprovação não reduziram no Ensino } \\
\text { Médio. }\end{array}$ & 4 & 5 & 4 & 80 & $2^{0}$ \\
\hline
\end{tabular}

\section{Detalhamento do problema}

Utilizou-se o Diagrama de Causa e Efeito para detalhar o problema:

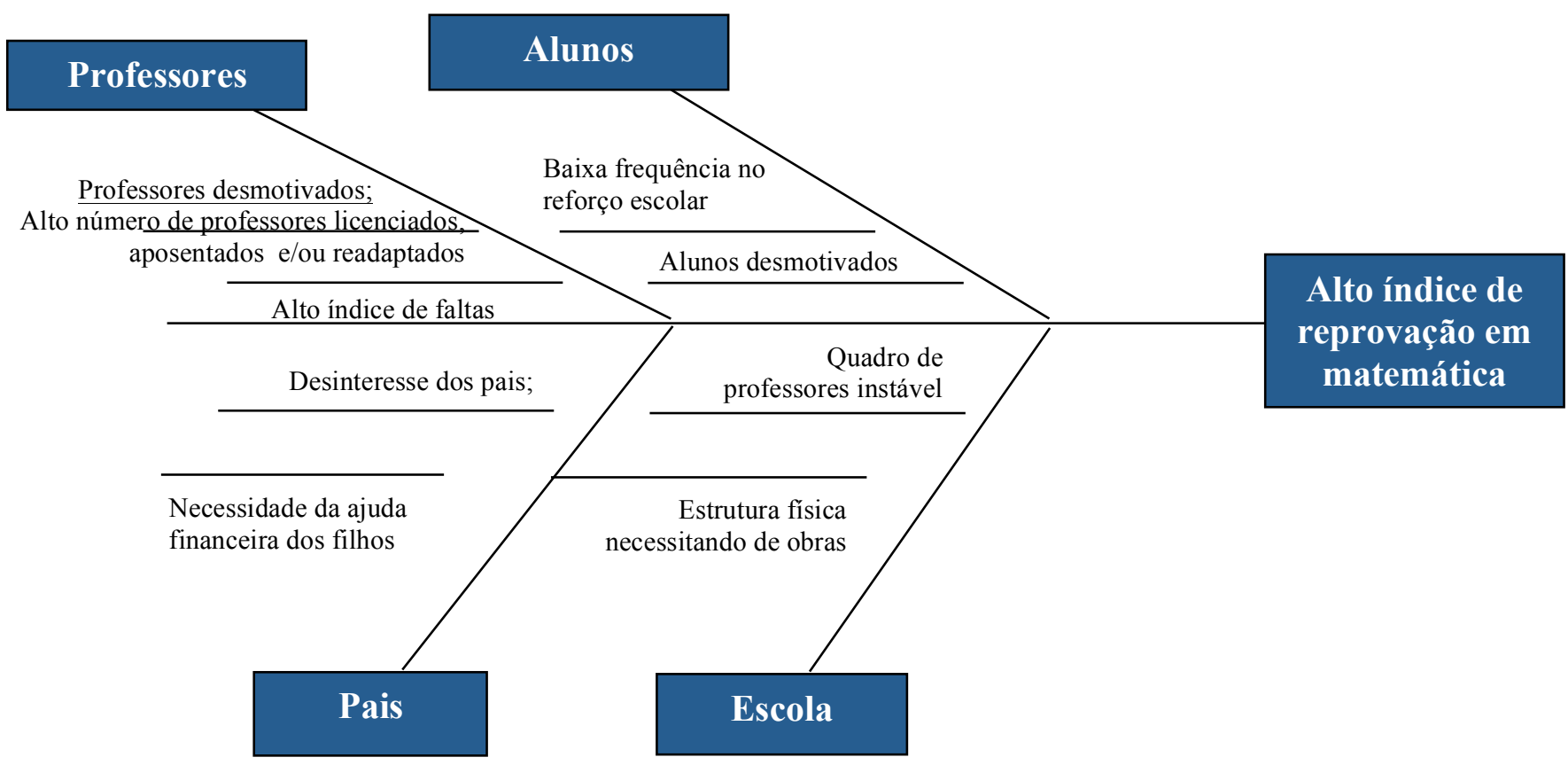




\section{Análise SWOT}

A partir das pesquisas realizadas pela equipe escolar, análise detalhada dos dados apresentados e discussões sobre o contexto da escola, foi desenvolvida a seguinte Matriz SWOT:

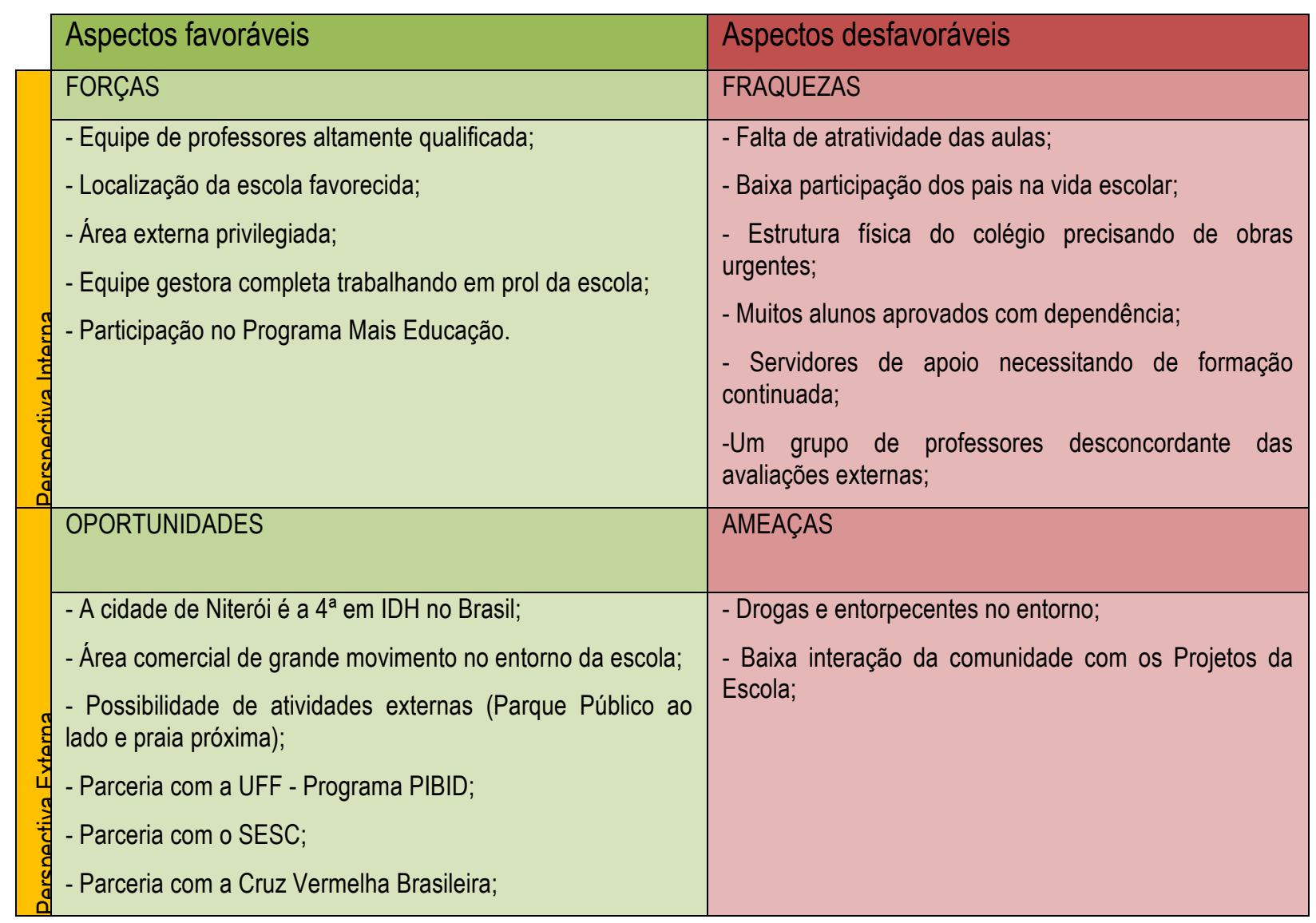

Analisando a matriz podemos observar que a escola tem grandes possibilidades, possuindo mais forças do que fraquezas. Os professores são qualificados e experientes, a boa localização favorece a implementação de diversos projetos e a escola já mantém algumas parcerias bastante proveitosas.

No entanto, observamos o descrédito de alguns professores nas avaliações externas, o desinteresse dos alunos nas aulas e muito pouca participação dos pais nas ações desenvolvidas na escola, além da falta de acompanhamento da vida escolar dos alunos. Este fator, comum em diversas escolas, foi agravado pela carência de professores, causando uma defasagem enorme na área de exatas, com reprovações e dependências.

\section{Ações corretivas}

Visando preparar a organização para o desenvolvimento do projeto, no intuito combater as fraquezas e reduzir os possíveis impactos das ameaças, foram definidas as seguintes ações:

Elaborar ações para o oferecimento de mais recursos aos professores favorecendo aulas mais atrativas;

Adotar iniciativas que estimulem os educandos dos anos/séries mais adiantadas a auxiliarem as turmas de anos anteriores.

Estabelecer mais parcerias que possam contribuir com ações criativas para a melhoria da aprendizagem dos alunos;

Reorganizar os setores do colégio com base nas prioridades detectadas, capacitando os funcionários de acordo com as funções desenvolvidas;

Incentivar a participação dos pais e alunos através da divulgação mais efetiva dos projetos desenvolvidos; 


\section{Oportunidade identificada}

A ideia central do projeto é desenvolver atividades que estimulem os educandos dos anos/ séries mais adiantadas a auxiliarem as turmas de anos anteriores visando envolvê-los nos processos de escolarização. Para isso pretende manter parceria com instituições como a Universidade Federal Fluminense - UFF - para proporcionar suporte acadêmico à "monitoria". Desta forma, os próprios alunos seriam monitores de seus colegas, incentivando-os e auxiliando-os a debater e sanar dúvidas na área de matemática. Os alunos monitores, estudantes do ensino médio regular, receberão uma remuneração pelo trabalho desenvolvido.

O colégio abrirá inscrição de alunos do Ensino Médio para monitoria e os professores selecionarão os mais qualificados. Um professor da área coordenará o trabalho dos monitores, que atuarão numa sala ambiente de matemática.

Observamos que muitos alunos acabam abandonando a escola por dificuldade de conjugar a carga horária da escola regular com a carga horária de seus cursos e lou estágios. Com esta parceria pretendemos oportunizar novas experiências aos nossos alunos, tornando-os responsáveis pelo bom rendimento do grupo, além de contribuírem para 0 aumento da renda familiar. Desta maneira, o aluno se mantém vinculado à escola não apenas por sua formação básica, mas atrelando a ela a sua capacitação profissional inicial. Como nesta proposta o foco é o aluno, pretendemos conseguir que uns estimulem os outros a participarem de um reforço coletivo, interagindo na construção do conhecimento e reduzindo substancialmente o percentual de reprovações em matemática.

\section{Detalhamento DO SERVIÇO:}

\section{Foco do projeto}

Este projeto tem por objetivo estabelecer uma equipe de monitoria que trabalhará em parceria com a equipe docente, promovendo encontros para estudo dirigido.

Série ou conjunto de séries beneficiadas: $9^{\circ}$ Ano do Ensino Fundamental, $1^{\circ}, 2^{\circ}$ e $3^{\circ}$ Anos do Ensino Médio Regular

Disciplina trabalhada: Matemática

\section{Etapas do projeto}

O projeto será composto pelas seguintes etapas:

Etapa 1 - Título da etapa: Divulgação da monitoria e abertura de inscrições

Objetivo: Estimular o engajamento dos alunos de forma crítica e efetiva nos projetos pedagógicos da escola.

Impacto na aprendizagem: Nesta primeira etapa utilizaremos as mídias da escola (rádio escolar, blog e facebook) para divulgação do projeto e esperamos uma grande motivação da comunidade escolar nesta tarefa.

Atividades a serem realizadas:

\section{Atividade 1.1}

Descrição: Apresentação do projeto à comunidade, definindo o prazo e os critérios da inscrição. Para isto, será promovida a produção de cartazes, ações para divulgação do projeto e definição do controle de inscrições. Nesta etapa ocorrerá a organização e inauguração da sala ambiente de matemática

\section{Pré-Requisitos:}

1. Estar matriculado na escola e com frequência regular.

2. Apresentar boas notas em matemática. (Nota superior a seis - 6).

3. Ter sido aprovado no processo seletivo.

4. Ter disponibilidade de 4 horas semanais para a realização das atividades de monitoria. 
Duração: 1 mês

Recursos necessários: Rádio escolar, mídias digitais e cartazes para os murais da escola.

Equipe envolvida: Coordenação pedagógica, professores articuladores e professores de matemática, além da equipe da rádio escolar.

\section{Atividade 1.2}

Descrição: Organização de reuniões com professores para avaliação dos estudantes inscritos na seleção de 5 monitores. Divulgação dos resultados à comunidade, reunião com os monitores para orientação detalhada do projeto.

\section{Funções do monitor:}

- Cooperar na recepção e integração dos alunos com a disciplina, tornando-se um "elo" entre os professores e os estudantes;

- Colaborar na discussão sobre o processo de avaliação dos alunos.

-Cumprir as horas semanais de atividade de monitoria, conforme os horários preestabelecidos;

- Zelar pelo patrimônio e nome da Instituição.

Duração: 1 mês

Recursos necessários: Pastas para fichas; rádio escolar, mídias digitais e cartazes para os murais da escola.

Equipe envolvida: Coordenação pedagógica, professores articuladores e professores de matemática e monitores

\section{Etapa 2 - Título da etapa: Início da monitoria}

Objetivo: Promover a construção do conhecimento dos conceitos matemáticos de forma coletiva e desenvolver o espírito do trabalho participativo e responsável.

Impacto na aprendizagem: O projeto pretende propiciar uma relação de troca de conhecimento entre professor/aluno e aluno/aluno, reduzindo as taxas de reprovação escolar.

\section{Atividade 2.1}

Descrição: 0 monitor deve se encarregar de acompanhar as atividades propostas pelo professor-coordenador trabalhando com um grupo de, no máximo, 15 alunos por horário de monitoria. Deverá montar um esquema de acompanhamento das atividades (planilha, gráfico, ficha, etc.) para apresentar ao final de cada bimestre e também transmitir ao professor as dificuldades observadas nos grupos.

Duração: 08 meses

Recursos necessários: Computadores, apostilas com exercícios de fixação, tabelas e gráficos.

Equipe envolvida: Coordenação pedagógica, professores articuladores, professores-coordenadores da disciplina e monitores.

\section{Etapa 3 - Título da etapa: Avaliação da monitoria}

Objetivo: Avaliar o desenvolvimento do projeto de forma individual e coletiva.

Impacto na aprendizagem: A prática da monitoria representa uma oportunidade para os estudantes compreenderem a importância da constante atualização e do empreendimento na própria formação, além de exigir comprometimento e responsabilidade. A autoavaliação permite que o educando reveja sua postura e os erros cometidos, visando uma melhoria do processo de aprendizagem.

\section{Atividade 3.1}

Descrição: O monitor deverá realizar uma autoavaliação de seu trabalho e promover também a dos alunos do 
projeto. Do mesmo modo, os professores envolvidos farão uma avaliação dos resultados obtidos com 0 projeto, preparando um relatório para ser apresentado à comunidade no final de cada ano letivo.

Duração: 1 mês

Recursos necessários: Fichas de autoavaliação.

Equipe envolvida: Coordenação pedagógica, professores articuladores, professores-coordenadores da disciplina, monitores e alunos.

\section{Caso de sucesso}

Nome do Projeto: "Monitoria: uma possibilidade de transformação no ensino-aprendizagem no Ensino Médio"

Nome da organização: Escola Estadual Cônego José Eugênio de Faria

Local: Cachoeira de Minas - Sul de Minas Gerais

Período em que foi realizado: julho de 2006

Breve relato do contexto anterior ao projeto: A escola detectou algumas carências típicas das escolas de Ensino Médio: falta de incentivo dos pais, falta de objetivo e perspectivas dos alunos, falta de respaldo aos alunos com maiores dificuldades e, principalmente, falta de correlação entre a construção de habilidades e competências e a vida prática, levando a uma queda nos resultados das avaliações externas.

Principais atividades desenvolvidas: A proposta nessa escola foi trabalhar com seis disciplinas do currículo do Ensino Médio numa monitoria diferenciada, já que propunha um trabalho de monitoria simultâneo ao trabalho do professor, dentro da sala de aula, numa espécie de trabalho orientado com grupos de 3 a 4 alunos, sendo 1 o monitor.

Resumo dos principais resultados alcançados: A equipe observou um aumento considerável na participação dos alunos, embora não apresente os resultados obtidos nas avaliações externas.

Fonte: $h t t p: / / w w w . s a p i e n t i a . p u c s p . b r / t d e \_b u s c a / a r q u i v o . p h p ? c o d A r q u i v o=8885$

(Acesso em 13/09/2014 às 20h)

\section{Novidade trazida pelo projeto}

O trabalho de monitoria é muito comum em cursos de graduação. E, como já apresentado, foi utilizado em escolas públicas de Minas Gerias. Além disto, há algum tempo diversos colégios e cursos particulares também adotam esta prática no ensino médio, conforme apresentado, por considerar benéfica a atuação do aluno junto aos demais, numa relação de parceria, de aprendizado colaborativo. 0 projeto apresenta a possibilidade de trazer este tipo de trabalho para as escolas públicas estaduais do Rio de Janeiro. 
Cronograma de execução

\begin{tabular}{|c|c|c|c|c|c|c|c|c|c|c|c|c|c|}
\hline \multirow{2}{*}{\multicolumn{2}{|c|}{ Atividades }} & \multicolumn{4}{|c|}{ Ano 1} & \multicolumn{4}{|c|}{ Ano 2} & \multicolumn{4}{|c|}{ Ano 3} \\
\hline & & Jan- & Abr- & Jul- & Out- & Jan- & Abr- & Jul- & Out- & Jan- & Abr- & Jul- & Out- \\
\hline \multirow{2}{*}{ Etapa 1} & Ativ. 1.1 & & & & & & & & & & & & \\
\hline & Ativ. 1.2 & & & & & & & & & & & & \\
\hline Etapa 2 & Ativ. 2.1 & & & & & & & & & & & & \\
\hline Etapa 3 & Ativ. 3.1 & & & & & & & & & & & & \\
\hline
\end{tabular}

Gestão estratégica

Objetivos estratégicos

\begin{tabular}{|c|c|c|c|}
\hline Objetivos & Metas & Indicadores & Acompanhamento \\
\hline \multirow{2}{*}{$\begin{array}{l}\text { Aumentar o } \\
\text { nível de } \\
\text { compreensão } \\
\text { dos alunos em } \\
\text { conceitos } \\
\text { matemáticos }\end{array}$} & $\begin{array}{l}\text { Aumentar o número de } \\
\text { aprovações em matemática } \\
\text { em } 10 \% \text { ao final do primeiro } \\
\text { ano de projeto; }\end{array}$ & $\begin{array}{lr}\text { Resultados } & \text { das } \\
\text { avaliações } & \text { de } \\
\text { matemática } & \text { por } \\
\text { turma. } & \end{array}$ & $\begin{array}{l}\text { Controle mensal do rendimento } \\
\text { das turmas e definição de } \\
\text { ações corretivas para } \\
\text { replanejamento, levando em } \\
\text { consideração também } \\
\text { feedback de alunos e } \\
\text { professores. }\end{array}$ \\
\hline & $\begin{array}{lrr}\text { Alcançar } & \text { a } & \text { meta } \\
\text { estabelecida } & \text { no } & \text { IDEB de } \\
4,5 \text { em 2015. } & & \end{array}$ & $\begin{array}{l}\text { Resultado da } \\
\text { avaliação externa } \\
\text { IDEB para o ano } \\
\text { de } 2015 .\end{array}$ & $\begin{array}{l}\text { Controle de habilidades e } \\
\text { competências } \\
\text { estabelecimento de para } \\
\text { específicas com base nas } \\
\text { avaliações anuais. }\end{array}$ \\
\hline $\begin{array}{l}\text { Possibilitar a } \\
\text { aprendizagem } \\
\text { e utilização de } \\
\text { diferentes } \\
\text { linguagens } \\
\text { matemáticas }\end{array}$ & $\begin{array}{l}\text { Aumentar o percentual de } \\
\text { acertos na disciplina em } \\
5 \% \text {, por ano de } \\
\text { escolaridade, ao final do } \\
\text { ano letivo. }\end{array}$ & $\begin{array}{l}\text { Notas obtidas no } \\
\text { SAERJ de } 2015 \\
X \text { notas obtidas } \\
\text { no SAERJ de } \\
2014\end{array}$ & $\begin{array}{l}\text { Reuniões bimestrais com os } \\
\text { professores de matemática da } \\
\text { escola para avaliar o } \\
\text { rendimento do grupo envolvido } \\
\text { nos SAERJINHOs. }\end{array}$ \\
\hline $\begin{array}{l}\text { Desenvolver o } \\
\text { hábito do } \\
\text { trabalho } \\
\text { coletivo } \\
\text { favorecendo a } \\
\text { estruturação do } \\
\text { pensamento } \\
\text { lógico }\end{array}$ & $\begin{array}{l}\text { Elevar em } 15 \% \text { a } \\
\text { participação dos alunos em } \\
\text { aulas de reforço escolar }\end{array}$ & $\begin{array}{l}\text { Percentual de } \\
\text { frequência nas } \\
\text { aulas de reforço } \\
\text { escolar }\end{array}$ & $\begin{array}{l}\text { Planilha de frequência no } \\
\text { reforço escolar e/ou nas aulas } \\
\text { de monitoria }\end{array}$ \\
\hline
\end{tabular}




\section{Continuidade do projeto}

Após o primeiro ano do projeto a equipe pedagógica fará uma análise dos resultados obtidos e os possíveis ajustes para o funcionamento nos próximos anos, revendo condições de prorrogação do mesmo para abranger também outras turmas e outras disciplinas.

\section{Marketing e comunicação}

\section{Lançamento do projeto}

O lançamento do projeto será feito, inicialmente, para o grupo de professores na reunião de planejamento pedagógico do final do ano letivo de 2014, na qual serão discutidos os projetos que serão desenvolvidos pelo colégio visando melhoria da qualidade de ensino. Esta é uma oportunidade de ajustar o projeto à demanda do colégio.

No início do ano letivo, na primeira reunião de planejamento, será feita a organização e registro de todos os projetos que serão implementados. Na segunda quinzena do ano letivo, será realizada uma feira interdisciplinar para todo o colégio com o objetivo de apresentar aos alunos e a comunidade os projetos que serão desenvolvidos. Nesta feira ocorrerá uma palestra sobre monitoria e aprendizagem colaborativa, seguida da inauguração da sala ambiente de matemática.

\section{Canais de comunicação e acompanhamento do projeto \\ Marketing interno}

Durante 0 ano letivo, a comunidade poderá acompanhar 0 andamento do projeto através de informes quinzenais na rádio escolar, na página do facebook do colégio e no blog da biblioteca escolar.

\section{Marketing externo}

O colégio disponibilizará um espaço no facebook para que os alunos possam se comunicar com os monitores. Além disto, manterá no mural de informes um local destinado à monitoria, que poderá ser atualizado periodicamente ou sempre que houver alguma mudança nos horários dos monitores ou no lugar de atendimento da monitoria.

\section{Parceiros estratégicos}

Professores da escola - acompanhamento e suporte pedagógico ao projeto;

Universidade Federal Fluminense - UFF (PIBID) - A escola já mantém uma parcria com a universidade que implementa a inserção dos universitários no contexto das escolas públicas para que desenvolvam atividades didático-pedagógicas sob orientação de um docente da UFF e um professor do colégio. A UFF também colaborará realizando uma palestra sobre monitoria e aprendizagem colaborativa.

Grêmio escolar e rádio escolar - Divulgação do projeto à comunidade escolar.

IBGE e IPEA - Responsáveis pelo fornecimento de dados estatísticos para análise e estudo dos nossos alunos.

\section{Divulgação de resultados}

A cada reunião bimestral para Conselho de Classe os monitores deverão informar aos seus professorescoordenadores 0 andamento das atividades que vem sendo realizadas, 0 desempenho dos alunos monitorados e a planilha de frequência nas aulas de monitoria.

Após as reuniões, os responsáveis pelo projeto elaborarão um relatório no qual será divulgado, utilizando as mídias da escola e as reuniões de pais, para toda a comunidade, o andamento dos alunos envolvidos na monitoria. 


\section{Equipe do projeto}

\section{Equipe interna}

Para dar andamento ao projeto o colégio disponibilizará os serviços do:

\begin{tabular}{|c|c|c|c|c|}
\hline Cargo & Formação & $\begin{array}{l}\text { Tempo na } \\
\text { escola }\end{array}$ & Experiência anterior & $\begin{array}{l}\text { Responsável pelas } \\
\text { atividades: }\end{array}$ \\
\hline Diretor Geral & Pedagogia & 2 anos & $\begin{array}{l}\text { Gestão de escola } \\
\text { localizada } \\
\text { comunidade de risco em }\end{array}$ & Supervisão \\
\hline Diretor Adjunto & MBA Gestão & 2 anos & $\begin{array}{l}\text { Gestão de escola de } \\
\text { Educação Especial }\end{array}$ & $\begin{array}{l}\text { Acompanhamento } \\
\text { do projeto }\end{array}$ \\
\hline $\begin{array}{l}\text { Coordenador } \\
\text { Pedagógico }\end{array}$ & Pedagogia & $\begin{array}{l}2 \text { anos e } 6 \\
\text { meses }\end{array}$ & $\begin{array}{l}\text { Coordenação de } \\
\text { projetos pedagógicos } \\
\text { em Márica }\end{array}$ & Apoio pedagógico \\
\hline $\begin{array}{l}\text { Professor } \\
\text { Articulador }\end{array}$ & Mestrado em Física & 8 anos & $\begin{array}{l}\text { Responsável pela Casa } \\
\text { da descoberta da UFF }\end{array}$ & $\begin{array}{l}\text { Acompanhamento } \\
\text { dos monitores }\end{array}$ \\
\hline $\begin{array}{l}\text { Professor } \\
\text { Coordenador }\end{array}$ & $\begin{array}{lr}\text { Graduação } & \text { em } \\
\text { matemática } & \mathrm{e} \\
\text { Engenharia } & \end{array}$ & 6 anos & $\begin{array}{l}\text { Professor (sócio) de } \\
\text { curso para Pré- } \\
\text { vestibulandos }\end{array}$ & $\begin{array}{l}\text { Orientação } \\
\text { Monitores }\end{array}$ \\
\hline
\end{tabular}

\section{Profissionais externos}

Contaremos com a participação:

\begin{tabular}{|l|l|l|}
\hline Tipo de profissional & Competências necessárias & Participação no projeto \\
\hline Professor da UFF & Docência universitária & Palestra de motivação \\
\hline Monitores & Aluno da escola (En. Médio) & Monitor \\
\hline
\end{tabular}

\section{Plano Financeiro}

Para execução do projeto serão necessárias as seguintes despesas:

\begin{tabular}{|l|l|l|l|}
\hline Obras e infraestrutura & Ano 1 & Ano 2 & Ano 3 \\
\hline Obras (pintura) & 600,00 & 0,00 & 300,00 \\
\hline Instalações elétricas & $1.200,00$ & 0,00 & 0,00 \\
\hline Total & $1.800,00$ & 0,00 & 300,00 \\
\hline
\end{tabular}


Obra de pintura e instalações elétricas para adaptação dos computadores e do aparelho de ar condicionado da sala ambiente de matemática.

\begin{tabular}{|l|l|l|l|}
\hline Material permanente & Ano 1 & Ano 2 & Ano 3 \\
\hline Cadeira universitária & $2.100,00$ & 210,00 & 210,00 \\
\hline Computadores & $3.200,00$ & $1.700,00$ & 0,00 \\
\hline Estante de aço & 119,00 & 0,00 & 0,00 \\
\hline Armário com chave & 400,00 & 0,00 & 0,00 \\
\hline Mesa do professor & 320,00 & 0,00 & 0,00 \\
\hline Ar condicionado & $1.600,00$ & 0,00 & 0,00 \\
\hline Total & $7.739,00$ & $1.910,00$ & 210,00 \\
\hline
\end{tabular}

Cadeira universitária: $\mathrm{R} \$ 105,00$ cada - Ano 1- 20 un; Ano 2- 2 un; Ano 3- 2 un

Computador Inspiron DT Série 3000 Dell: R\$1.600,00 - Ano 1- 2 un; Ano 2- 1 un

Estante de Aço: Com 5 prateleiras - R\$119,00

Armário com chave: Com 3 prateleiras - $\mathrm{R} \$ 400,00$

Mesa do professor: Modelo FDE com cadeira - R $\$ 320,00$

Ar condicionado: Ar Condicionado Split Samsung Max Plus 18000 BTUs - R\$ 1.600,00

Despesas correntes:

Para implementação e funcionamento do projeto serão necessários:

\begin{tabular}{|l|l|l|l|}
\hline Material de consumo & Ano 1 & Ano 2 & Ano 3 \\
\hline Material de Papelaria & 612,00 & 648,72 & 687,64 \\
\hline Material de informática & 360,00 & 381,60 & 404,50 \\
\hline Material de desenho/ medição & 180,00 & 190,80 & 202,25 \\
\hline Total & $1.476,00$ & $1.564,56$ & $1.658,43$ \\
\hline
\end{tabular}

Papel chamex, resma $\mathrm{R} \$ 22,00$

Caneta esferográfica: $R \$ 34,50-50$ unidades

Pillot para quadro branco: $\mathrm{R} \$ 5,50$ cada

Cartucho toner p/Brother preto. TN410 Brother - CX 1 UN R $\$ 90,00$

Conjunto para desenho com esquadros e transferidor: $R \$ 12,30$

Trena: $R \$ 5,30$

Metro de madeira: $\mathrm{R} \$ 15,00$

\begin{tabular}{|l|l|l|l|}
\hline Serviços de terceiros & Ano 1 & Ano 2 & Ano 3 \\
\hline Monitores & 14.400 .00 & 15.264 .00 & 16.179 .84 \\
\hline Palestrante & 1.800 .00 & - & - \\
\hline Total & $16.200,00$ & $15.264,00$ & $16.179,84$ \\
\hline
\end{tabular}




\section{Contrapartida}

Em contrapartida, nosso colégio oferecerá os seguintes profissionais:

\begin{tabular}{|l|l|l|l|}
\hline \multicolumn{4}{|l|}{ Projeção das Despesas Administrativas e de Pessoal } \\
\hline Administrativas & Total ANO 1 & Total ANO 2 & Total ANO 3 \\
\hline Secretaria & $1.224,00$ & $1.297,44$ & $1.375,29$ \\
\hline Servente & 817,20 & 866,23 & 918,21 \\
\hline Conta de luz & 324,00 & 343,44 & 364,05 \\
\hline Total & $2.365,20$ & $2.507,11$ & $2.657,54$ \\
\hline Pessoal & Total ANO 1 & Total ANO 2 & Total ANO 3 \\
\hline Diretor Geral & $1.488,00$ & $1.577,28$ & $1.671,92$ \\
\hline Diretor Adjunto & $3.060,00$ & $3.243,60$ & $3.438,22$ \\
\hline $\begin{array}{l}\text { Coordenador } \\
\text { Pedagógico }\end{array}$ & $3.672,00$ & $3.892,32$ & $4.125,86$ \\
\hline Professor Articulador & $6.174,00$ & $6.544,44$ & $6.937,11$ \\
\hline $\begin{array}{l}\text { Professores } \\
\text { coordenadores }\end{array}$ & $7.408,80$ & $7.853,33$ & $8.324,53$ \\
\hline Total & $21.802,80$ & $23.110,97$ & $24.497,63$ \\
\hline $\begin{array}{l}\text { Total das Despesas } \\
\text { Correntes }\end{array}$ & $24.168,00$ & $25.618,08$ & $27.155,16$ \\
\hline
\end{tabular}

\section{Recursos do edital}

\begin{tabular}{|l|l|l|l|l|}
\hline Tipo de item & Ano 1 & Ano 2 & Ano 3 & Total \\
\hline Despesas de Capital & $9.539,00$ & $1.910,00$ & 510,00 & $11.959,00$ \\
\hline Obras e infraestrutura & $1.800,00$ & 0,00 & 300,00 & $2.100,00$ \\
\hline Material permanente & $7.739,00$ & $1.910,00$ & 210,00 & $9.859,00$ \\
\hline Despesas Correntes & $17.352,00$ & $16.485,12$ & $17.474,23$ & $51.311,35$ \\
\hline Material de consumo & $1.152,00$ & $1.221,12$ & $1.294,39$ & $3.667,51$ \\
\hline Serviços de terceiros & $16.200,00$ & $15.264,00$ & $16.179,84$ & $47.643,84$ \\
\hline Total do projeto & $26.891,00$ & $18.395,12$ & $17.984,23$ & $63.270,35$ \\
\hline
\end{tabular}

Com este projeto, que atende aos requisitos do edital, o Colégio Estadual Joaquim Távora pretende trazer resultados positivos para esta comunidade escolar, introduzindo o hábito do estudo coletivo, reduzindo as taxas de reprovação e colaborando para o alcance das metas federais e estaduais de desempenho escolar. 


\section{ANEXOS}

\section{Pesquisa realizada na Escola}

Objetivo da pesquisa: Identificar o nível de satisfação dos clientes/usuários com os serviços oferecidos pela escola.

Tipo de pesquisa: descritiva.

Método de coleta de dados: obtenção de dados primários por meio de uma survey.

Instrumento de coleta de dados: questionário.

Questionário

Informe seu ano/série:

Como você avalia o ensino oferecido pela nossa escola?

Como você avalia as instalações/espaço físico da nossa escola?

Como você avalia os banheiros da nossa escola?

Como você avalia as aulas ministradas pelos professores?

Como você avalia o material didático e os recursos utilizados em sala de aula?

Como você avalia os serviços prestados pela secretaria?

Como você avalia a cordialidade e 0 atendimento prestado pelos demais funcionários da escola?

Como você avalia a variedade de alimentos da merenda escolar?

Como você avalia a Biblioteca?

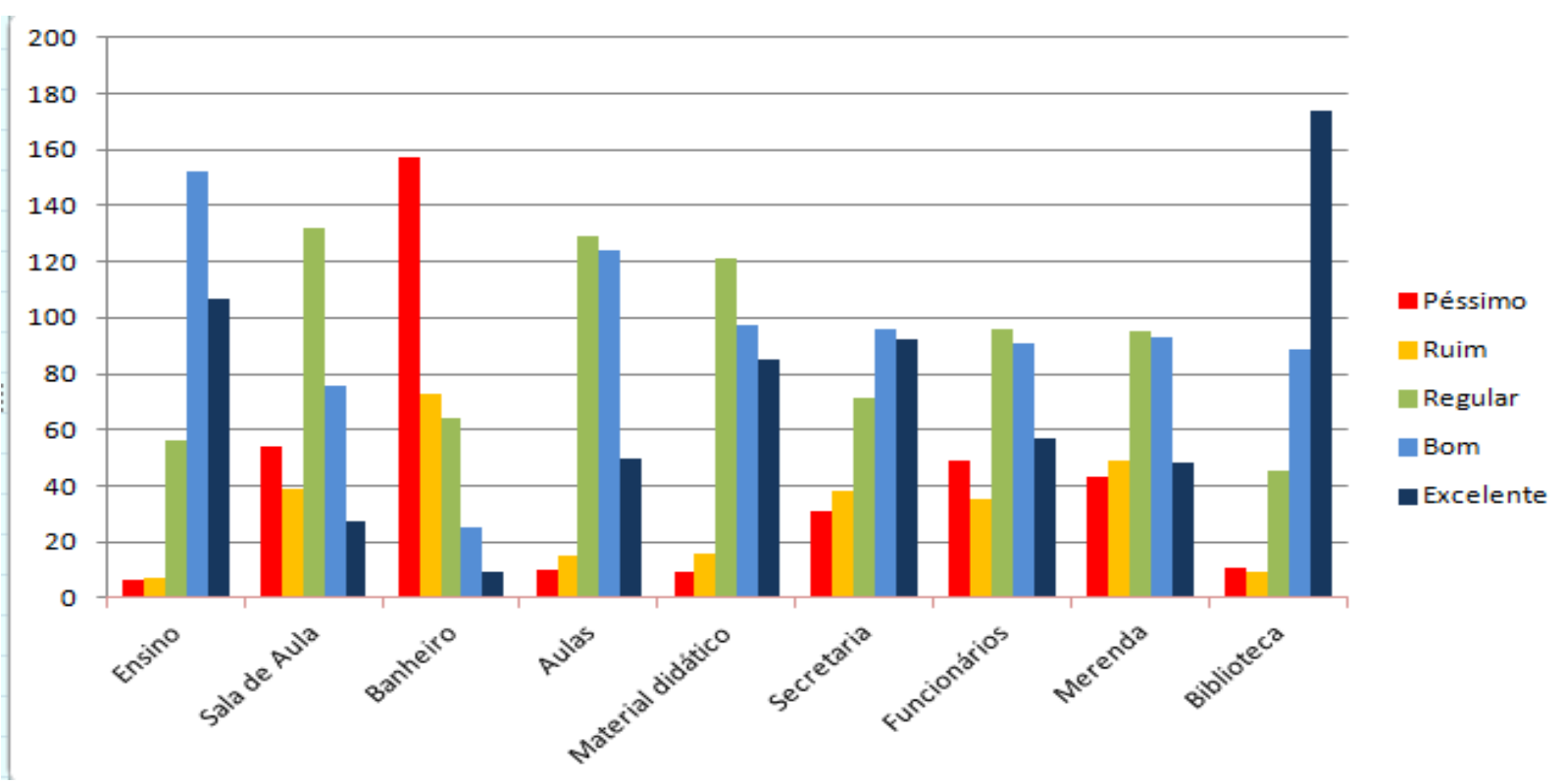



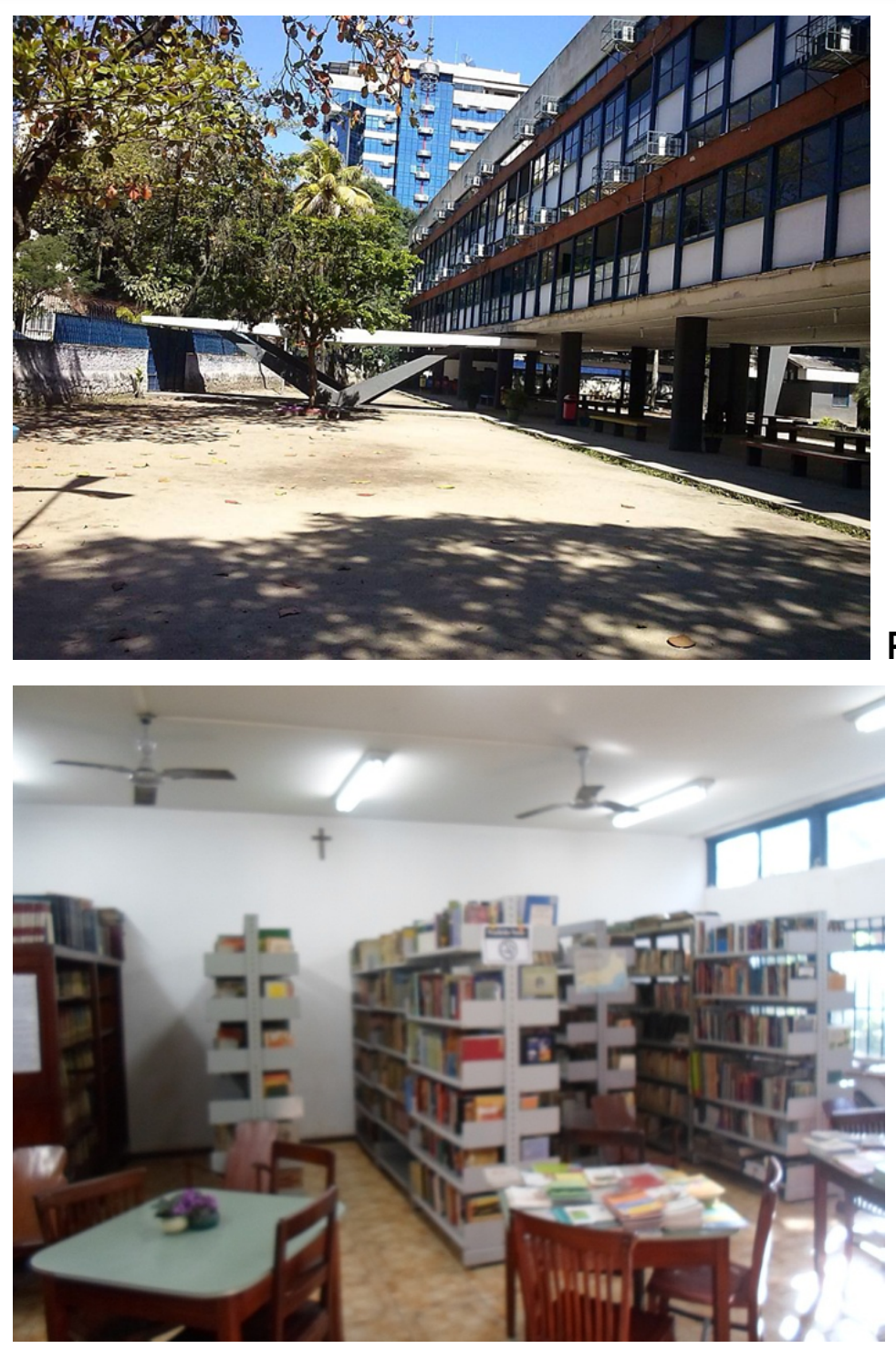

Pátio coberto

Biblioteca 